\title{
A Seamless Learning Design for Mobile Assisted Language Learning: An Iranian Context
}

\author{
Elham Mohammadi Foomani ${ }^{1} \&$ Mohsen Hedayati ${ }^{2}$ \\ ${ }^{1}$ University of Tehran, Iran \\ ${ }^{2}$ University of Tasmania, Australia \\ Correspondence: Elham Mohammadi Foomani, University of Tehran, Iran. E-mail: \\ foomanielham@alumni.ut.ac.ir
}

Received: February 1, 2016 Accepted: April 14, 2016 Online Published: April 18, 2016

doi: 10.5539/elt.v9n5p206

URL: http://dx.doi.org/10.5539/elt.v9n5p206

\begin{abstract}
Recent developments in information communication technology (ICT) have resulted in a paradigm shift in e-Learning and there is a growing interest in developing design-based research (DBR) focusing on learners and their involvement in knowledge sharing in a contextualized mode. The present study reports a mobile-assisted language learning (MALL) design with a focus on contextualized student-created content having a seamless learning approach. The students in this study $(\mathrm{N}=24)$ used their mobile devices to take photos and create artifacts to represent English idioms and share them on Padlets with their peers for further discussion and feedback. In the first four weeks of the study, students were taught English idioms and in the following next two weeks they created and shared their own artifacts to represent the learnt idioms. The post-study reflections and results of the interviews and obtained from students and the teacher at the end of study revealed that they favor and support greater learner autonomy achieved by learner-generated context (LGC) which bridges the in-classroom and out-of-classroom learning. The article also highlights the necessity of reconceptualization of teachers and students' perceptions of mobile use in language learning in Iran.
\end{abstract}

Keywords: e-Learning, MALL, mobile seamless learning, artifact creation, collaborative learning, learner-generated context

\section{Introduction}

With the continuous advances in technology the nature of learning approaches also undergo gradual changes. Technology impacts the learning environment (Kim, 2011), and in the case of handhelds as Kukulska-Hulme (2006) puts it: "One of the key advantages of mobile technology with regard to learning-related communication is considered to be the way in which it helps overturn traditional concepts of how learning spaces should be organized" (p. 120). The technology-based approach makes the students more interested and more frequent in using language in the internet than in the traditional approaches (Kim, 2008). As the current devices propose a ready-to-hand access (Wong \& Looi, 2011; Wong \& Looi, 2010) to the knowledge sources, the potential for the evolution of a new trend in technology enhanced learning increases. The students can continually experience learning across different contexts in a seamless learning space with one device per learner (Looi \& Wong, 2014; Looi et al., 2010). While the vast learning opportunities in different contexts and in students' everyday lives could complement the formal learning, it is often neglected by teachers and students (Wong, Chen, \& Jan, 2011). One of the key features of technology enhanced learning, whether through e-learning or m-learning, is the 'anytime', 'anywhere' concept of the learning. With one device per learner students can learn whenever and wherever they have the motivation (Chan et al., 2006; Wong \& Looi, 2011). Chan et al. (2006) identify two pedagogical goals for a seamless learning design: First students can learn whenever they are curious to learn and second, it is possible for the students to switch between different learning scenarios.

Although some may regard the new advancements as a threat to learners' actively engaging in the physical world, through proper planning of learning designs with an emphasis on learners' interactions with the physical world (Rogers \& Price, 2008) it is possible that technology strengthens the links between the learners and the physical reality (Wong, Chen, \& Jan, 2011). With the increasing interest in creating language learning environments in which authentic and mobile assisted learning encompass, it is proposed that blending CALL paradigm with mobile learning can be regarded a proper solution for reconciling learning contexts and real life (Wong \& Looi, 
2015; Wong \& Looi 2010), thus increase students' achievement (Looi \& Wong, 2014).

This paper reports on a seamless language learning design with an analytic method to analyze the role of artifacts in mediating Iranian EFL learners' language learning. The study takes a mobile-assisted language learning approach with a focus on contextualized content creation of the students and the process of meaning-making in their daily lives.

\section{Review of the Related Literature}

\subsection{Computer Assisted Language Learning}

Extensive research has been conducted on technology-mediated language learning. As the language learning trends move from traditional behaviorist approaches towards communicative and constructive approaches (Chuo, 2004) we also witness gradual shifts of the trends in the field of computer-assisted language learning (CALL). Previously many studies dealt with the role of computer softwares on: pronunciation training (e.g. Neri, Cucchiarini, Strik, \& Boves, 2002), vocabulary teaching (e.g. Ma \& Kelly, 2006) and learning through games (e.g. Saffarian \& Gorjian, 2012; Yu, Chang, Liu, \& Chan, 2002). More recent studies emphasize the learners and the possibility for learners to engage in online collaborative activities (e.g. Kessler, 2009; Kessler \& Bikowski, 2010; Shih, 2011; Ware, 2004).

\subsection{Mobile Assisted Language Learning}

$\mathrm{Yu}$ (2007) identifies three generations of mobile-assisted learning, the first generation is about transferring learning content, the second deals with mobile learning designs and the third one introduces learning in a 1:1 setting and context-aware learning. Technology enhanced learning is undergoing a paradigm shift from e-learning to m-learning (Rushby, 2005) and from m-learning to context-aware u-learning (Liu \& Hwang, 2010). While the focus in the first generation was on mobile devices as effective means of transferring learning content (Thornton \& Houser, 2005) and most content based studies focused on using SMS for vocabulary learning (Alemi, Anani Sarab, \& Lari, 2012; Chen, Hsieh, \& Kinshuk, 2008; Derakhshan \& Kaivanpanah, 2011; Kim, 2011; Tabatabaei, 2012; Thornton \& Houser, 2005), more recent studies focus on learner-generated context using mobile phones.

Kukulska-Hulme (2005) notes that MALL is intriguing in the sense that it has the potential to provide rich, real-time, contextual and collaborative learning experiences in and out of the classes. As Kukulska-Hulme (2009) mentions an intriguing feature of learning via mobile technology is that learning can move indoors and outdoors. It challenges the formal-informal dichotomy and connects learning experiences (Looi et al., 2010) and thus reduces the distance between physical and digital world (Kulkuska-Hulme, 2006). Studies have proposed varied designs and technologies to support mobile classroom-based learning: context-aware learning with the use of GPS or RFID tags to present location-related information (Rogers \& Price, 2008; Shih, 2010), the use of pedagogical strategies and technology for on-going context-aware learning (Sandberg, Maris, \& de Geus, 2011), and the use of technology for ubiquitous learning: (Chang \& Chen, 2007; Ogata, Akamatsu, \& Yano, 2004).

\subsection{Mobile Seamless Learning}

While in the previous generations of m-learning the learner was confined in the formal learning context with the teacher planned materials, the new generation or mobile seamless learning (MSL) combines the formal and informal contexts (Wong \& Looi, 2011). Seamless learning is defined as a learning model in which students can learn whenever they are curious in different learning scenarios, using a device as a mediator (Chan et al., 2006). As Wong (2012) argues, "seamless learning mediated by 1:1 setting is referred to as mobile seamless learning (MSL)" (p. 19). Wong and Looi (2011) investigated the meaning of seamless learning and attempted to identify the potential ways of implementing it. Wong and Looi (2010) suggested that the diversity of expositions and studies indicate that the MSL model is a multi-aspect and multi-dimensional model. More recently, Wong et al. (2015) proposed a more comprehensive definition of seamless learning as "when a person experiences a continuity of learning, and consciously bridges the multifaceted learning efforts, across a combination of locations, times, technologies or social settings." (p. 10)

\subsection{MSL Literature}

Some studies focused on defining and elaborating on the concept of seamless learning (e.g. Chan et al., 2006), while other researchers attempted to propose concrete seamless designs (e.g. Looi et al., 2010; Wong et al., 2015; Yu, Yang, \& Cheng, 2009). Some studies advocate limited use of devices in form of one off-activity designs (e.g. Chang \& Chen, 2007; Ogata, Akamatsu, \& Yano, 2004; Rogers \& Price, 2008; So, Seow, \& Looi, 2009; Yang, 2006), some other studies venture to support the use of $1: 1$ and $24 * 7$ learning experiences (e.g. Looi \& Wong, 2014; Looi et al., 2010; So et al., 2009; Wong, Chin, Tan \& Liu, 2010; Yu et al., 2009). Some researchers support 
the notion of mobile device as a "learning hub" (e.g. Looi et al, 2010; Wong \& Looi, 2010; Wong et al., 2010). However, some other researchers go for the combined use of multiple devices (e.g. Chang \& Chen, 2007). Somewhere in the middle of the continuum, some argue that the combined use of mobile and stable technologies is the best approach (Wong, 2012). Ng and Nicholas (2007) argue that "at least in the mainstream school education context, seamless learning requires planned interactions between mobile and stable technologies." (p. 189)

Finally while some encourage collaborative activities (Kessler, 2009; Ogata, Akamatsu, \& Yano, 2004; Shih, 2011; Wong \& Looi, 2010), it is argued that personalized learning should not be neglected; thus they believe in creating a balance between personalized and collaborative models (Chang \& Chen, 2007; Looi et al., 2010).

This study advocates a combination of personalized and collaborative activities with the mixed usage of a mobile device and a stable technology in a $24 * 7$ design. The rational for choosing this design is to promote collaborative learning while fostering individual autonomy in creating learning scenarios.

\section{Methodology}

\subsection{Participants}

The participants of the study were 24 male and female EFL students taking a general English class in Zaban-Sara language institute in Zanjan, Iran. With regard to English proficiency, based on the institute's placement test, they were intermediate level students. They shared similar backgrounds and their age ranged from 20 to 31 .

\subsection{The Seamless Design}

The seamless design of this study consisted of 4 phases. In the first phase which lasted for 8 sessions in 4 weeks, the teacher allocated 15 minutes of every classroom session for teaching 4 idioms. In the second phase which was taking place simultaneously, the students were divided into 4 study groups and were asked to collaboratively make artifacts for the 4 idioms they were taught every session. They took 2-3 photos for each idiom in their real-life contexts using their mobile devices to illustrate the idiom and made sentences for the photos to describe what they meant. In the third phase and the last 2 weeks of the study, the 8 groups of the students shared their artifacts, i.e. the photos, the idiom associated with it and the sentence describing the photos online. The students individually commented on, corrected and reviewed each artifact and compared and voted for the artifact which best described each idiom. The teacher helped facilitate the discussions when necessary. In the last phase which was simultaneous with the 2 weeks of online sharing and commenting, the teacher allocated 15 minutes of every session for the discussions on the online tasks. The students introduced the best artifacts selected and the winner group presented a talk on the artifact creation procedure and the thought regarding the processes they went through.

The rationale behind dividing the students into study groups was to promote collaborative learning processes and increase student motivation for their out-of-class learning. With the creation of artifacts students could closely observe the environment for upcoming learning opportunities and in the collaborative sense they could share the idea with friends. The design focused on learners' association of real-life contexts with language use. This artifact-oriented, context aware approach helps foster a habit among students of creating in situ learning resources in any learning space (Wong, Chen, \& Jan, 2011). Another rationale for this design is that traditional approaches to vocabulary teaching have been criticized on delivering second-hand decontextualized experiences, while in this method contextualized learning in fostered. Specifically in the case of idiom internalization this context aware design emphasizes the contextual use of idioms in authentic environments.

\subsection{Research Design}

A variety of data collection and analysis methods was used to capture the cross contextual nature of seamless learning. A dynamic assessment of students' internalization of the idioms was conducted in the course of the classes by the teacher to evaluate the design effectiveness in students' idiom gains. At the end of the 4 phases of the design, an interview was administered to the students to check their thought processes in idiom-context associations; they were required to self-report their perceptions and experiences in different contexts for the selected idioms. The interviews were analyzed based on the framework proposed by Wong et al. (2010). They identified three types of cognitive processes in artifact creation:

- Artifact creation with an idiom in mind: finding or creating a context that corresponds to an idiom and then photo taking

- Encountering a context or scenario and then associating it with an idiom and photo taking (immediate association) 
- Encountering or creating a context or scenario, photo taking and then associating it with an idiom (delayed association)

Wong et al. (2010) suggest that the three types of processes correspond to 3 vocabulary learning strategies. Type 1 is considered the easiest process which is used most often by the learners who are new to the artifact creation process. Type 2 is the most complicated process where the relevant idioms should immediately pop up in the learners' minds and needs prior internalization of the idioms. Type 3 is considered a bridging strategy between type 1 and type 2 . The information gained from artifact creation processes and the vocabulary strategy types were categorized and the descriptive statistics was conducted for a better understanding of the students' behaviors.

In the next step, in order to conduct an in-depth analysis of the students' attitudes and perceptions with regard to the seamless design, they were asked to report their perceptions of the learning experience in the course of the study in individual semi-structured interview sessions. The interviews were conducted by the researcher in 10 minutes with the following questions:

- Do you think the seamless learning design for acquiring the idioms is interesting? Why or Why not?

- Do you think this learning approach can be useful for idiom internalization? Why or Why not?

- $\quad$ Are you satisfied with your idiom learning in this design? Why or Why not?

- Did you find the online discussions motivating or useful in the learning process? What challenges did you encounter?

Student answers to these 3 questions were transcribed and subsequently analyzed to gain an insight into their overall attitudes towards the learning approach.

In the last step, an interview was conducted with the teacher to gain an insight into the teacher's perception and the possible challenges encountered. The following 2 questions were posed:

- Do you think the design can be useful for teaching idioms? Why and why not?

- What challenges did you encounter through the 6 week course of the study? In what ways do you think the design can be improved?

The interview results will be discussed in the following sections.

\section{Findings}

\subsection{Descriptive Statistics of Students'Artifact Creation}

Throughout the first four weeks of the study, the students created 125 sets of artifacts and shared 24 of them online. Based on the interviews, various analyses were performed on the data in order to derive patterns. Table 1 . presents the descriptive statistics for the learners' cognitive processes in artifact creations across different contexts.

Table 1. Contexts vs. the cognitive process types

\begin{tabular}{llllll}
\hline & Type 1 & Type 2 & Type 3 & Not Sure & Total \\
\hline Institute & 17 & 9 & 2 & 2 & 30 \\
Home & 11 & 4 & 11 & 1 & 27 \\
Workplace/University & 12 & 5 & 7 & 0 & 24 \\
Outdoor & 13 & 9 & 20 & 2 & 44 \\
Total & 53 & 27 & 40 & 5 & 125 \\
\hline
\end{tabular}

Table 1 was generated based on the interview results with students. The artifact creation contexts were classified into four settings of institute, home, workplace (university), and outdoor. In five of the cases the students did not remember how they created the artifacts so the cognitive process type could not be identified; these cases were categorized under Not Sure. As indicated in Table 1. The process Type 1 was the most prevalent strategy among the students and outdoor was the most frequently used setting for artifact creation. Type 3 ranked second where students used the previously taken photos to create artifacts. As stated earlier Type 2 requires a more complicated thought process and is an indicator of the idiom internalization and thus is more popular among more proficient 
artifact creators. In this study where the students were new to artifact creation, only $21 \%$ of the artifacts created were of Type 2 cognitive process.

\subsection{Interview Results}

The interview results with the students and the teacher indicated their interest $(78 \%)$ in the seamless learning design. $75 \%$ of the students were satisfied with their knowledge gains and $78 \%$ of them regarded the design useful for idiom learning, even though some students mentioned that sometimes artifact creation was difficult for some more abstract idioms. With regard to their online discussions, the students pointed out that comments and reviews were motivating and the peer assessment strategy helped them improve their artifact creation (80\%) as well as their language abilities (48\%). However some of them mentioned incorrect comments of their peers as annoying and suggested more active presence of the teacher in the discussions.

The analysis of the interview with the teacher revealed that he considered the design useful for idiom learning, although he identified some challenges in the artifact creation process and the online discussions. He believed that the design could be improved by training the students as to the artifact creation and that the peer assessment challenges in the virtual space should be taken into account in prospective designs.

\section{Discussion}

As indicated in Table 1 The students created artifacts using type 1 cognitive process more frequently than the other two more complex process types, which is justifiable regarding the fact that the students were novice artifact creators. Type 3 use ranked second in the table. Through the analysis of the artifacts and the interviews with the students, it was revealed that the students used their older photos to combine with the recent photos and create associated artifacts. A total of 40 artifacts were created using this process type. Wong (2013) regards these cases of using photos taken across time and location as transforming the mobile device from a productive tool to a cognitive one. Figure 1 is an artifact created by a student using type 3 process.



Figure 1. Sentence: "when I feel depressed, I hang out with my family, they are apple of my eyes."

The artifacts were created across different settings. A significant fact regarding settings is that the students used their older outdoor photos to create the artifacts more frequently, which makes outdoor as a prominent setting in this study. On the other hand a great deal of Type 1 artifacts were created first in the institute and then outdoor where the students often met for artifact creation purposes and only the simplest process type was possible with their having an idiom in mind. This justifies the fact that only in two of the cases type 2 process was used in the institute. As Table 1 shows the students used type 1 and type 3 equally when they were at home, which is an indicator of students' spending a great deal of their time and learning at home.

With the analysis of the artifacts and the interview results we noticed that in some cases the students failed to create idiom associated artifacts. They believed that the idioms were abstract thus difficult to depict in photos. This is while the other students managed to create acceptable artifacts for the idioms. This might be an indicator of a need to train the students as to the artifact creation techniques and processes. The students should be trained and encouraged to engage in deeper processes to be able to use type 2 and fully internalize the idioms. In order to diminish the virtual space challenges, the teacher needs to spend a great deal of time and effort as a monitor and facilitator to student discussions, encouraging the less motivated students, intervening peer assessment mistakes while taking into account their feelings.

\section{Conclusion}

This study reported on a seamless learning design where despite most MALL studies the scope of students' 
learning was not restricted to behaviorist facilitated contexts (Chen \& Li, 2010; Ogata, Akamatsu, \& Yano, 2004; Sandberg et al., 2011). Instead, Learner Generated Context, which stimulates constructivist, active meaning making among students through establishing the habit of seeking for limitless learning opportunities in everyday life experiences as well as virtual spaces, is the core of this design. It instills in them the habit to become actively involved in generating learning resources and become more autonomous learners. To conclude, based on the teachers' reflections and the students' responses to the interviews the seamless learning design proved efficient in idiom learning. The learners had greater opportunities to observe their peers online and to learn both the idioms and artifact creation skills, to modify their work and improve its quality. Furthermore online reviews provided opportunities for social interactions in a virtual environment thus enhancing sharing perspectives and experiences in a learning environment. Although there were limitations and challenges to the study which should have taken into account, this seamless design integrated three factors of learner generated context, 1:1 learning and $7 * 24$ environment. Further studies should be conducted to investigate diverse seamless designs and under different circumstances so as to acknowledge a better perspective on the most effective designs for learning different language features. Future designs should take into account regarding the role of teachers as well as the challenges in peer assessment in online procedures.

\section{References}

Alemi, M., Anani Sarab, M-R., \& Lari, Z. (2012). Successful learning of academic word list via MALL: Mobile Assisted Language Learning. International Education Studies, 5(6), 99-109. http://dx.doi.org/10.5539/ies.v5n6p99

Chan, T.-W., Roschelle J., Hsi S., Kinshuk, Sharples M., Brown T., ... Hoppe U. (2006). One-to-one technology-enhanced learning: an opportunity for global research collaboration. Research and Practice in Technology-Enhanced Learning, 1, 3-29. http://dx.doi.org/10.1142/S1793206806000032

Chang, C.-S., \& Chen, T.-S. (2007). Building self-knowledge for learners in ubiquitous learning grid. Paper presented at the Technology Enhanced Learning Conference 2007, Jhongli, Taiwan.

Chen, N. S., Hsieh, S. W., \& Kinshuk. (2008). Effects of short-term memory and content representation type on mobile language learning. Language Learning \& Technology, 12(3), 93-113.

Chen, C.-M., \& Li, Y.-L. (2010). Personalized context-aware ubiquitous learning system for supporting effective English vocabulary learning. Interactive Learning Environments, 18(4), 341-364. http://dx.doi.org/10.1080/10494820802602329

Chuo, T.-W. I. (2004). The application of computer technology in foreign language instruction. Languages, Literacy Studies and International Studies, 1, 15-33.

Derakhshan, A., \& Kaivanpanah, S. (2011). The impact of text-messaging on EFL freshmen's vocabulary learning. EUROCALL, 39-47.

Kessler, G. (2009). Student initiated attention to form in wiki based collaborative writing. Language Learning \& Technology, 13(1), 79-95.

Kessler, G., \& Bikowski, D. (2010). Developing collaborative autonomous learning abilities in computer mediated language learning: attention to meaning among students in wiki space. Computer Assisted Language Learning, 23(1), 41-58. http://dx.doi.org/10.1080/09588220903467335

Kim, H-S. (2008). A study of L2 hypertext reading in the Korean university context. Korean Journal of Applied Linguistics, 24(3), 303-328.

Kim, H-S. (2011). Effects of SMS text messaging on vocabulary learning. Multimedia-Assisted Language Learning, 14(2), 159-180.

Kukulska-Hulme, A. (2005). The mobile language learner now and in the future. Fran Vision till Praktik. Language Learning Symposium, Umea University, Sweden.

Kukulska-Hulme, A. (2006). Mobile language learning now and in the future. In: Svensson, Patrik ed. Fr an vision till praktik: Spr akutbildning och Informationsteknik (From vision to practice: language learning and IT). Sweden: Swedish Net University (N"atuniversitetet), 295-310.

Kukulska-Hulme, A. (2009). Will mobile learning change language learning? ReCALL, 21(2), 157-165. http://dx.doi.org/10.1017/S0958344009000202

Liu, G., Z., \& Hwang, G., J. (2010). A key step to understanding paradigm shifts in e-learning: towards context-aware ubiquitous learning. British Journal of Educational Technology, 41(2), 1-9. 
http://dx.doi.org/10.1111/j.1467-8535.2009.00976.x

Looi, C.-K., Seow, P., Zhang, B. H., So, H.-J., Chen, W., \& Wong, L.-H. (2010). Leveraging mobile technology for sustainable seamless learning: A research agenda. British Journal of Educational Technology, 42(1), 154-169. http://dx.doi.org/10.1111/j.1467-8535.2008.00912.x

Looi, C.-K., \& Wong, L-H. (2014). Implementing mobile learning curricula in schools: A programme of research from innovation to scaling. Educational Technology \& Society, 17(2), 72-84.

Ma, Q., \& Kelly, P. (2006). Computer assisted vocabulary learning: Design and evaluation. Computer Assisted Language Learning, 19(1), 15-45. http://dx.doi.org/10.1080/09588220600803998

Neri, A., Cucchiarini, C., Strik, H., \& Boves L. (2002). The pedagogy-technology interface in computer assisted pronunciation training. Computer Assisted Language Learning, 15(5), 441-468. http://dx.doi.org/10.1076/call.15.5.441.13473

Ng, W., \& Nicholas, H. (2007). Ubiquitous learning with handhelds in schools. Proceedings of the International Conference on Mobile Learning 2007 (pp. 186-193), Melbourne, Australia.

Ogata, H., Akamatsu, R., \& Yano, Y. (2004). Computer supported ubiquitous learning environment for vocabulary learning using RFID tags. Paper presented at the Workshop on Technology Enhanced Learning, 04, Toulouse, France. http://dx.doi.org/10.1007/0-387-24047-0_10

Rogers, Y., \& Price, S. (2008). The role of mobile devices in facilitating collaborative inquiry in situ. Research

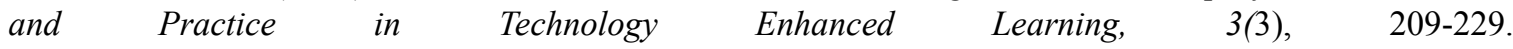
http://dx.doi.org/10.1142/S1793206808000525

Rushby, N. (2005). Editorial. British Journal of Educational Technology, 36(5), 709-710. http://dx.doi.org/10.1111/j.1467-8535.2005.00556.x

Saffarian, R., \& Gorjian, B. (2012). Effect of computer-based video games for vocabulary acquisition among young children: An experimental study. Journal of Comparative Literature and Culture, 1(3), 44-48.

Sandberg, J., Maris, M., \& de Geus, K. (2011). Mobile English learning: An evidence-based study with fifth graders. Computers \& Education, 57(1), 1334-1347. http://dx.doi.org/10.1016/j.compedu.2011.01.015

Shih, R., C. (2010). Blended learning using video-based blogs: Public speaking for English as second language students. Australasian Journal of Educational Technology, 26(6), 883-897.

Shih., R., C. (2011). Can Web 2.0 technology assist college students in learning English writing? Integrating Facebook and peer assessment with blended learning. Australasian Journal of Educational Technology, 27(5), 829-845.

So, H.-J., Seow, P., \& Looi, C.-K. (2009). Location matters: Leveraging knowledge building with mobile devices and Web 2.0 technology. Interactive Learning Environment, 17(4), 367-382. http://dx.doi.org/10.1080/10494820903195389

Tabatabaei, O., \& Goojani, A-H. (2012). The impact of text-messaging on vocabulary learning of Iranian EFL learners. Cross-cultural Communication, 8(2), 47-55.

Thornton, P., \& Houser, C. (2005). Using mobile phones in English education in Japan. Journal of Computer Assisted Learning, 21(3), 217-228. http://dx.doi.org/10.1111/j.1365-2729.2005.00129.x

Ware, P., D. (2004). Confidence and competition online: ESL student perspectives on web based discussions in the classroom. Computers and Composition, 21(4), 451-468. http://dx.doi.org/10.1016/S8755-4615(04)00041-6

Wong, L.-H. (2012). A learner-centric view of mobile seamless learning. British Journal of Educational Technology, 43(1), 19- 23. http://dx.doi.org/10.1111/j.1467-8535.2011.01245.x

Wong, L.-H., Chen, W., \& Jan, M. (2011). How artefacts mediate small group co-creation activities in a mobile-assisted seamless language learning environment? Journal of Computer Assisted Learning. http://dx.doi.org/10.1111/j.1365-2729.2011.00445.x

Wong, L.-H., Chin, C.-K., Tan, C.-L., \& Liu, M. (2010). Students' personal and social meaning making in a Chinese idiom mobile learning environment. Educational Technology \& Society, 13(4), 15-26.

Wong, L.-H., \& Looi, C.-K. (2010). Vocabulary learning by mobile-assisted authentic content creation and social meaning-making: two case studies. Journal of Computer Assisted Learning, 26, 421-433. http://dx.doi.org/10.1111/j.1365-2729.2010.00357.x 
Wong, L.-H., \& Looi, C.-K. (2011). What seams do we remove in mobile assisted seamless learning? A critical review of the literature. Computers \& Education, 57(4), 2364-2381. http://dx.doi.org/10.1016/j.compedu.2011.06.007

Wong, L. H., Chai, C. S., Aw, G. P., \& King, R. B. (2015). Enculturating seamless language learning_through artifact creation and social interaction process. Interactive Learning Environments, 23(2), 130-157. http://dx.doi.org/10.1080/10494820.2015.1016534

Yang, S. J. H. (2006). Context aware ubiquitous learning environments for peer-to-peer collaborative learning. Educational Technology \& Society, 9(1), 188-201.

Yu, S. (2007). Development and prospect of three generations of mobile learning: Knowledge transfer, cognitive construction and situated cognition. China Educational Technology, 6.

Yu, F. Y., Chang, L. J., Liu, Y. H., \& Chan, T. W. (2002). Learning preferences towards computerised competitive modes. Journal of Computer Assisted Learning, 18(3), 341-350. http://dx.doi.org/10.1046/j.0266-4909.2002.00245.x

Yu, S., Yang, X., \& Cheng, G. (2009). Learning resource design and sharing in ubiquitous learning environment: The concept and architecture of learning cell. Open Education. Research, 15(1), 47-53.

\section{Copyrights}

Copyright for this article is retained by the author(s), with first publication rights granted to the journal.

This is an open-access article distributed under the terms and conditions of the Creative Commons Attribution license (http://creativecommons.org/licenses/by/3.0/). 